\title{
A CONTRIBUIÇÃO DA ANÁLISE TEXTUAL DISCURSIVA PARA COMPREENDER O PIBID COMO COMUNIDADE DE PRÁTICA
}

\section{THE CONTRIBUTION OF DISCURSIVE TEXTUAL ANALYSIS TO UNDERSTAND PIBID AS A COMMUNITY OF PRACTICE}

\author{
Marcus Eduardo Maciel Ribeiro ${ }^{1}$ \\ Maurivan Güntzel Ramos ${ }^{2}$
}

\begin{abstract}
Resumo: Este artigo apresenta a Análise Textual Discursiva (ATD) em processo na análise de depoimentos de licenciandos e professores de Química, todos participantes do Programa Institucional de Bolsas de Iniciação à Docência (Pibid), em seis subprojetos de Química em Instituições de Ensino Superior no estado do Rio Grande do Sul, Brasil, nos anos de 2015 e 2016. Buscou-se responder a seguinte pergunta: de que modo a ATD pode contribuir para compreender o impacto na formação e na prática docente de professores de Química, no âmbito do Pibid, na forma de uma comunidade de prática? Participaram da pesquisa 41 licenciandos e 13 professores de Química egressos do Programa. As informações da pesquisa foram produzidas por meio de entrevistas semiestruturadas e de questionários. A análise dos depoimentos dos participantes justifica a tese de que as ações realizadas no Pibid ocorrem na forma de comunidades de prática, pois sua estrutura se assemelha a alguns dos pressupostos teóricos aceitos para esse modo de formação. A ATD mostrou-se adequada e potente metodologia de tratamento de informações nesta investigação qualitativa.
\end{abstract}

Palavras-chave: Análise Textual Discursiva; Pibid; Comunidade de Prática; Formação de Professores.

\begin{abstract}
This paper introduces the Discursive Textual Analysis (DTA) in the analysis of testimonies given by undergraduates and Chemistry teachers who participated in the Institutional Program for Teaching Initiation Scholarships (PIBID) in six Chemistry subprojects in Higher Education Institutions in Rio Grande do Sul state, Brazil, in 2015 and 2016. It aims to answer the following question: how can the DTA contribute to understand its impact on Chemistry teachers' education and teaching practice, within the scope of the PIBID as a community of practice? Forty-one undergraduates and thirteen Chemistry teachers who had graduated in the program took part in the study. Information was collected in semi-structured interviews and questionnaires. The analysis of participants' testimonies justifies the thesis that actions carried out in the PIBID occur as communities of practice, since their structure is similar to some theoretical assumptions that are accepted in this type of education program. The DTA proved to be an adequate and potent methodology to treat information in this qualitative investigation.
\end{abstract}

Keywords: Discursive Textual Analysis; PIBID; Community of Practice; Teacher Education.

\section{Introdução}

Assim como outros países, o Brasil apresenta quantidade de professores aquém da necessidade percebida em suas escolas. Essa necessidade implica dificuldades em relação

\footnotetext{
${ }^{1}$ Doutor em Educação em Ciências e Matemática pela Pontifícia Universidade Católica (PUCRS). Professor do Instituto Federal de Educação, Ciência e Tecnologia Sul-riograndense (IFSul), Novo Hamburgo-RS, Brasil. E-mail: profmarcus@yahoo.com.br

${ }^{2}$ Doutor em Educação pela Pontifícia Universidade Católica (PUCRS). Professor da Pontifícia Universidade

Católica (PUCRS), Porto Alegre-RS, Brasil. E-mail: mrgamos@ pucrs.br
} 
aos processos de formação dos professores, criando um intervalo entre a necessidade de aumentar a quantidade de profissionais e a de prepará-los com qualidade. É desejável que mais egressos do Ensino Médio optem pela profissão de professor e que os cursos de formação tenham condições de melhor preparar os novos profissionais. O que se espera desses futuros professores e, em especial, dos licenciandos de Química é que se formem a partir de teorias e práticas que contribuam efetivamente para a qualidade da área do ensino. Isso é tão importante quanto atualizar-se somente na perspectiva técnica de sua disciplina. Nessas teorias e práticas educativas, espera-se uma interação entre o professor, o aluno, a escola e a universidade, com práticas contextualizadas e com significado no âmbito do ensino de Química.

Considerando esse contexto, este artigo tem o objetivo de apresentar o processo de Análise Textual Discursiva (ATD) (MORAES; GALIAZZI, 2011), associado à compreensão de licenciandos e professores egressos do Programa Institucional de Bolsas de Iniciação à Docência (Pibid), em relação à sua participação em subprojetos de Química nesse Programa. Com isso, alguns impactos podem emergir em relação à formação e à prática docente de professores de Química, no âmbito do Pibid, na forma de uma comunidade de prática. A investigação ${ }^{3}$ ocorreu durante os anos de 2015 e 2016 no contexto de subprojetos de Química existentes naquele período. O problema de pesquisa traduziu-se por meio da seguinte questão: de que modo a Análise Textual Discursiva pode contribuir para compreender o impacto na formação e na prática docente de professores de Química, no âmbito do Pibid, na forma de uma comunidade de prática? Buscou-se identificar, a partir do uso da ATD como metodologia das informações obtidas, de que forma o Pibid interfere nas concepções e na prática dos professores de Química a partir de sua inserção nas escolas e interação com o ambiente escolar.

O Pibid, criado em 2007 e implementado em 2008 junto a universidades e escolas de Educação Básica, é um programa que tem como objetivos contribuir para a qualificação da formação de professores, incentivar os licenciandos para que percebam a importância da profissão docente, promover uma necessária aproximação entre a universidade e a escola básica e promover a participação dos licenciandos em atividades docentes em escolas sob acompanhamento de supervisores.

\footnotetext{
${ }^{3}$ As informações sobre esta investigação, que serviu para a elaboração de uma tese de doutorado, podem ser encontradas em: RIBEIRO, M. E. M. A formação de professores em comunidades de prática por meio da participação no Pibid de Química em instituições de ensino superior no estado do Rio Grande do Sul. 2017. Tese (Doutorado em Educação em Ciências e Matemática) - Faculdade de Física, Pontifícia Universidade Católica do Rio Grande do Sul, Porto Alegre, 2017.
} 
Neste artigo, usam-se as seguintes denominações específicas: bolsista(s), quando se fizer referência aos licenciandos que participam do Programa; coordenador, para designar o coordenador da área de Química; supervisor(es), em referência ao professor de escola que acompanha os licenciandos; estudante( $(s)$, quando se falar dos estudantes de Educação Básica; e licenciado(s) para referência a egressos da licenciatura que atuaram no Pibid.

Participaram da pesquisa que deu origem a este artigo bolsistas de iniciação à docência e professores egressos desses subprojetos, tendo suas concepções expressas por meio de entrevistas e questionários. É sobre esse conjunto de textos (corpus), que serviu de base para a Análise Textual Discursiva, que se sustenta o artigo.

Os achados na análise trouxeram a compreensão de que os subprojetos do Pibid podem organizar-se na forma de uma Comunidade de Prática (WENGER, 1998). A participação de licenciandos no Pibid em reuniões sistemáticas na forma de uma Comunidade de Prática pode ajudá-los a apropriarem-se de concepções pedagógicas adequadas aos tempos atuais, afastando-se do modelo transmissivo e empirista.

\section{Pressupostos Teóricos}

Neste tópico, são abordados elementos teóricos que constituem a formação de professores, principalmente nos cursos de licenciatura (PIMENTA; LIMA, 2006), bem como propostas de formação de professores por meio das Comunidades de Prática (WENGER, 1998), que se constituem em grupos de discussão e partilha de experiências profissionais.

\subsection{A formação de professores de Química no Brasil}

A constituição das concepções docentes de um professor inicia ainda em seu tempo de estudante no Ensino Fundamental, por meio de observações de modelos de seus próprios professores em vivências cotidianas em salas de aula. Segundo Pimenta (1997, p. 7), "quando os alunos chegam ao curso de formação inicial, já têm saberes sobre o que é ser professor”. Esses saberes são constituídos em sua experiência de estudantes, pois estiveram frente a variadas propostas pedagógicas de seus professores. Afirma Pimenta (1997, p. 7) que os estudantes, ao chegarem à licenciatura, demonstram ter "experiência que lhes possibilita dizer quais foram os bons professores, quais eram bons em conteúdo, mas não em didática, isto é, não sabiam ensinar. Quais professores foram significativos em suas 
vidas, isto é, contribuíram para sua formação humana". Ainda, para a autora (1997), a licenciatura tem a função de promover a passagem de ver-se como estudante para ver-se como professor. Essa transição tem a propriedade de modificar as características do licenciando, fazendo com que assuma as funções de docente constituídas durante essa formação inicial. Essa observação continua durante seu tempo de licenciando, quando inicia sua preparação formal para a docência.

Desenvolve-se, nas disciplinas de didática, uma ilusão de que situações de ensino que ocorrem de fato nas escolas possam ser vivenciadas em atividades práticas na formação inicial. Dessa maneira, a formação no Ensino Superior, com frequência, apresenta formas de estágio que se resumem à tentativa de corrigir falhas observadas na escola, o que se configura em uma distorção do processo, uma vez que os licenciandos passam a criticar e rotular a escola e seus gestores.

A participação do novo professor em comunidades de formação permite que as vivências dos professores mais experientes possam ser apropriadas pelos mais novos. As questões referentes à formação de professores em uma comunidade foram discutidas por Ribeiro (2013, p. 42), quando afirma que "as comunidades de prática de professores podem gerar e gerenciar conhecimento por meio do compartilhamento de recursos. É mais conveniente do que professores que trabalham solitariamente, sem discutir suas práticas com seus colegas". Com isso, pretende-se argumentar que, no Pibid, reuniões de trabalho de bolsistas com seus supervisores e coordenadores do subprojeto podem ser eficientes meios de reconstrução do conhecimento pedagógico, tanto para esses bolsistas, pois permitem acessar esse novo conhecimento em suas experiências na escola, quanto para os coordenadores e supervisores.

Nesse sentido, a formação do professor de Química exige que, ao longo desse processo, o licenciando amplie seus conhecimentos sobre Química e sobre o ensinar Química. Para Talanquer (2004), é importante que os cursos de formação inicial e continuada tenham espaço para a discussão dos conteúdos a ensinar, sendo vistos sob a perspectiva da análise e da discussão didática. Ademais, a formação inicial necessita habilitar o professor a continuar em sua formação, pois os currículos dos cursos de Licenciatura em Química, em geral, propõem uma formação homogênea entre os licenciandos, deixando lacunas nessa formação, principalmente em disciplinas do núcleo pedagógico dos cursos. Segundo Gatti, Barretto e André (2011, p. 89), “essas lacunas mostram que as políticas relativas à formação inicial dos docentes no Brasil, no que se refere às instituições formadoras e aos currículos, precisariam ser repensadas". 
Para Schön (1992), deve-se valorizar a própria prática profissional como forma de construção do conhecimento do professor, a partir de momentos de reflexão. É nesse contexto dos processos de formação inicial (licenciandos) e continuada (de professores supervisores e coordenadores) que se inclui o Pibid. O Pibid é considerado pelos bolsistas de iniciação à docência uma atividade paralela aos estudos da licenciatura. Os bolsistas de iniciação à docência entrevistados mostram visível preferência pelas atividades do Pibid às disciplinas que compõem seu currículo escolar, incluindo aí aquelas do núcleo pedagógico e as do núcleo técnico.

\subsection{Os saberes dos professores}

A construção dos saberes docentes é influenciada pelos contextos que envolvem a formação dos professores, devendo ser consideradas as questões sobre a reflexão-na-ação e de racionalidade prática, mostradas por Schön (1992).

Entretanto, nota-se que, na ação docente dos professores, há uma distinção entre estas duas dimensões: as concepções do professor e sua prática. Os professores, em sua ação, mesmo que de forma implícita, consideram mais suas concepções já estabelecidas do que as teorias que eles mesmos defendem, ou seja, nem todos os professores têm consciência de suas teorias pessoais (ANIJOVICH; CAPPELLETTI, 2014). Uma forma de desenvolver essa consciência, para que possam transformá-la, é estudar, agir e refletir durante a formação.

Os grupos de estudos que recebem os professores em formação realizam pesquisas e elaboram estratégias que apresentam, em um primeiro momento, apenas resultados localizados, apenas identificáveis pelo próprio licenciando em formação. Becker (1995) discute essa situação, afirmando que as práticas docentes e organizações escolares usam teorias que não são necessariamente as mesmas produzidas em investigações em ciências da educação. Tardif (2014) afirma que a prática educativa, enquanto arte, é orientada por resultados exteriores ao professor. $\mathrm{Na}$ prática educativa enquanto arte, a prática do professor apresenta algumas dimensões, como: ter uma ideia do objetivo que quer atingir; conhecer o material com o qual trabalha; agir baseado na tradição; agir baseado em sua habilidade pessoal; agir baseando-se em sua experiência (TARDIF, 2014, p.159).

Segundo Pimenta (1997), o confronto dos saberes iniciais com as experiências práticas constitui os saberes docentes, em uma reflexão sobre a prática e na prática. Entretanto, decisões e práticas na escola também definem as ações e formam as 
representações do professor. Santos Júnior e Marcondes (2013, p. 699) afirmam que, “dessa forma, os professores são, de certo modo, coagidos a se organizar em torno de um projeto coletivo, que poderá não representar os anseios dos docentes". Logo, embora se reconheça a relevância do protagonismo e da autonomia do professor em suas escolhas, compreendese que estas são fortemente influenciadas pela própria escola.

Enquanto Tardif (2014) justifica os saberes docentes a partir de concepções e práticas dos professores, Schön (1992) sugere uma necessária reflexão sobre a prática. No mesmo sentido de Tardif, Pimenta e Schön, também Shulman (1987) apresenta suas concepções sobre a construção dos saberes docentes. Shulman (1987, p. 8) define categorias para classificar os conhecimentos (saberes) dos professores: conhecimento do conteúdo; conhecimento pedagógico geral; conhecimento pedagógico do conteúdo; conhecimento dos alunos e de suas características; conhecimento de contextos educacionais; conhecimento dos fins, propósitos e valores da educação e de sua base histórica e filosófica; e conhecimento do currículo.

Para Shulman (1987), assim como para Pimenta (1997), é necessária uma combinação entre distintas dimensões para compor os saberes docentes. Segundo Shulman,

[...] representa a combinação de conteúdo e pedagogia no entendimento de como tópicos específicos, problemas ou questões são organizados, representados e adaptados para os diversos interesses e aptidões dos alunos, e apresentados no processo educacional em sala de aula. O conhecimento pedagógico do conteúdo é, muito provavelmente, a categoria que melhor distingue a compreensão de um especialista em conteúdo daquela de um pedagogo (SHULMAN, 1987, p. 8).

Para a apropriação desses saberes, Shulman (1987) defende que a sua origem ocorra sobre quatro alicerces: a formação acadêmica nas áreas de conhecimento ou disciplinas; os materiais e o entorno do processo educacional institucionalizado (por exemplo, currículos, materiais didáticos, organização e financiamento educacional, e estrutura da profissão docente); pesquisas sobre escolarização, organizações sociais, aprendizado humano, ensino e desenvolvimento, e outros fenômenos sociais e culturais que afetam o que os professores fazem; e a sabedoria que deriva da própria prática. Esses alicerces estão discutidos em Ribeiro (2017).

Nesse contexto, a dimensão do saber docente manifesta-se em professores que apresentam alto grau de conhecimento pedagógico do conteúdo. Esses professores analisam o conteúdo, com o qual vão trabalhar de uma forma bastante distinta daquela dos novos professores, ainda em processo de formação, pois se apropriaram das questões de reflexão e análise em sua prática. 


\subsection{As Comunidades de Prática}

As comunidades de prática constituem uma proposta de grupos de discussão que pode ser compreendida como um espaço e processo de formação permanente para professores. Apesar de seu objetivo inicial ter sido para implantação como ferramenta administrativa em empresas, sua adaptação para o uso com professores parece adequada, mesmo havendo ainda poucos relatos desse tipo de situação. Segundo Imbernón (2009, p. 80), “[...] comunidades de prática são grupos constituídos com a finalidade de desenvolver um conhecimento especializado, mas não é uma comunidade científica. Compartilha aprendizagens baseadas na reflexão partilhada sobre experiências práticas”. É ideia central, em uma comunidade de prática, que os participantes levem para as discussões periódicas os problemas que vivenciam em sua prática, de maneira que, em um ambiente de discussão, se possam estabelecer novas propostas de ação. A participação do professor em uma comunidade pode contornar problemas específicos, colocando-os na discussão coletiva e permitindo que as informações recebidas junto a novos conhecimentos possam, por meio de discussão e reflexão, ganhar sentido.

As comunidades de prática de professores e de licenciandos podem gerar conhecimento por meio do compartilhamento de recursos. Esse compartilhamento é mais conveniente do que os professores que trabalham sozinhos, sem discutir suas práticas com seus colegas. A associação dos professores e licenciandos em comunidades de prática, além de beneficiar esses sujeitos, pode oferecer melhoria nos resultados dos estudantes. Durante os encontros, os professores podem refletir sobre sua prática, examinar as evidências dos resultados dos alunos e até mesmo discutir suas estratégias de ensino.

\subsubsection{A estrutura de uma comunidade de prática}

As ideias iniciais sobre a comunidade de prática foram estabelecidas por Wenger (1998, 2001, 2009). Não se trata de um órgão permanente de uma instituição que deva obediência a superiores e que deva apresentar relatórios finais. É nesse contexto que se inserem as reuniões do Pibid, em que se incluem bolsistas de iniciação à docência, professores supervisores e o coordenador do subprojeto, mas é possível fazer adaptações à realidade da formação de professores e do Pibid, por exemplo, em que textos, relatos escritos e narrativas são importantes elementos da formação.

A estrutura organizacional de uma comunidade de prática mostra um núcleo central com alguns participantes e uma região periférica constituída por um número maior de 
componentes. Os componentes periféricos podem reorganizar sua participação e, com o tempo, ingressar no núcleo central, bem como algum componente do núcleo pode diminuir sua participação e passar à marginalidade, isto é, voltar para a periferia da comunidade.

Uma comunidade de prática é um ambiente que pode estimular a participação de iniciantes na profissão. É importante que se criem círculos nos quais professores recémformados possam participar para que, além das abstrações teóricas, também possam experimentar a prática (WENGER, 2001; BRONFMAN, 2011).

Uma comunidade de prática se estabelece a partir das dimensões prática, comunidade, identidade e aprendizagem. A dimensão da prática "envolve mais que efetuar algo. Envolve participar de uma comunidade em atividades que resultem na aprendizagem e na produção de significados" (SANTOS; ARROIO, 2015, p. 21). A ideia de comunidade relaciona-se com a participação integrada em práticas compartilhadas. A identidade, terceira dimensão, é percebida na reunião das experiências de cada participante, de forma a caracterizar uma comunidade de fato. Santos e Arroio (2015, p. 22) afirmam que "a identidade é construída pela negociação de significados da experiência de cada pessoa como membro de comunidades locais, funcionando, assim, como ligação entre o social e o individual". Aprendizagem dos participantes de uma comunidade de prática é a quarta dimensão, em que a contrapartida também é observada. Assim como a participação na comunidade colabora com a aprendizagem dos sujeitos, também a própria comunidade é incentivada pela aprendizagem já constituída por cada participante. Segundo Santos e Arroio (2015, p. 22), "a aprendizagem é a engrenagem da prática, ao mesmo tempo em que a prática é a história da aprendizagem".

Assim, prática e aprendizagem têm íntima relação. A prática é um relato das histórias compartilhadas dos processos anteriores de aprendizagem e precursoras de novas aprendizagens. Para Ribeiro e Ramos (2019a, p. 640), “aprendizagem e prática não são transferidas, passadas ou entregues entre pessoas, mas construídas e apropriadas pelo convívio mútuo e reflexão daquilo que se faz", o que pode indicar que uma comunidade de prática seja um ambiente propício para um processo de formação mútua.

\section{Procedimentos Metodológicos}

A investigação teve abordagem qualitativa, segundo as concepções de Lüdke e André (2012). Tem-se que esta pesquisa não teve o objetivo de prever um resultado, o que 
denotaria uma ação positivista, mas de compreender as ações e modos de pensar dos participantes a partir da interpretação por meio da Análise Textual Discursiva.

\subsection{Contexto de pesquisa}

Os subprojetos de Química do Pibid estão presentes em todas as regiões do Brasil e, em especial, do estado do Rio Grande do Sul. Para esta investigação, foram escolhidas instituições de ensino superior (IES) de diferentes regiões desse estado, tendo como critério a existência de subprojeto de Química. Foram escolhidas seis IES, sendo três instituições públicas federais e três instituições comunitárias. Essas instituições são identificadas com os códigos de U1 a U6.

Neste artigo, encontram-se resultados da pesquisa que emergiram da participação de 41 bolsistas (identificados por letras em ordem alfabética junto aos códigos de suas instituições; U3B, por exemplo) e 13 professores egressos do Pibid (identificados pela letra $\mathrm{P}$, seguida do código da instituição e de um numeral em ordem crescente; P25, por exemplo). As concepções dos bolsistas de iniciação à docência foram obtidas a partir de entrevistas realizadas em grupos nos próprios subprojetos, enquanto que os professores egressos se manifestaram por meio de questionários.

\subsection{A Análise Textual Discursiva como metodologia de interpretação das concepções dos participantes da pesquisa}

A leitura da transcrição das entrevistas foi feita com o objetivo de encontrar semelhanças entre as manifestações dos sujeitos de IES diferentes. Em um momento inicial, tentou-se identificar a natureza de cada manifestação, atribuindo uma caracterização a cada fala. Esse movimento foi feito por meio de Análise Textual Discursiva (MORAES; GALIAZZI, 2011).

\subsubsection{A interpretação das informações obtidas: a Análise Textual Discursiva}

$\mathrm{Na}$ análise das manifestações ouvidas e lidas dos sujeitos da pesquisa, percebeu-se a necessidade de interpretá-las, a fim de compreender o sentido que os sujeitos davam às suas ideias. Os relatos das práticas, vivências, experiências, saberes e descobertas de cada bolsista e dos egressos do programa apontam para um mesmo fenômeno, porém, com consequências e significados diferentes. Ressalta-se considerar legítimo que diferentes olhares apresentem diferentes formas de compreensão de um mesmo fenômeno. 
Entrevistas com os bolsistas e questionários com professores egressos do programa foram os instrumentos de produção de informações. A análise desse material permitiu aos pesquisadores a percepção de convergências nas manifestações desses sujeitos.

O tratamento das informações por meio de Análise Textual Discursiva é um processo sucessivo de desconstrução e reconstrução do texto, objetivando a compreensão das concepções dos sujeitos que participam do processo. Segundo Ribeiro e Ramos,

\begin{abstract}
A ATD tem como etapa inicial do trabalho a fragmentação do texto, reduzindoo a ideias unitárias ou unidades de sentido, as quais são codificadas, para que se possa identificar sua origem, se necessário. Ao final da unitarização do texto, as unidades de sentido são agrupadas em função da semelhança de seu conteúdo, passando a constituírem categorias iniciais. No caso da análise de outro texto ou depoimento, é possível aproximar as unidades semelhantes às categorias iniciais do primeiro texto, e, se necessário, podem ser constituídas novas categorias (RIBEIRO; RAMOS, 2019, p. 641).
\end{abstract}

Esse processo de unitarização se estabelece em um movimento de reescrita das unidades. Nesse momento, já está iniciado o processo de releitura, pois o autor vai se impregnando do sentido do texto que está em análise e passa a atribuir sentido às unidades. Ramos, Ribeiro e Galiazzi (2015, p. 128) afirmam que "esse movimento possibilita um exercício de impregnação do pesquisador em relação ao texto que está sendo analisado. Nesse processo já existe interpretação por parte de quem analisa".

O movimento seguinte é uma aproximação entre as categorias iniciais, formando categorias mais amplas, construindo relações. Se o pesquisador tiver definido suas categorias antes do início da análise, elas são denominadas de categorias a priori. Se as categorias forem surgindo ao longo da análise, denominam-se categorias emergentes. Nesta investigação, as categorias formadoras do texto final emergiram ao longo da análise do material estudado. O conjunto de categorias que se estabeleceu originou-se da compreensão do pesquisador e da interlocução com teóricos, dos metatextos produzidos como propostas de respostas às questões de pesquisa.

\title{
3.3 A desconstrução do texto e a formação de categorias
}

O processo de análise dá-se a partir de um corpus de pesquisa. Para a pesquisa que é retratada neste artigo, o corpus constituiu-se das entrevistas com bolsistas do Pibid e de questionários aplicados a professores egressos deste programa.

Os primeiros movimentos de análise (a fragmentação, a reescrita e a identificação de palavras-chave) permitem que o pesquisador estabeleça uma relação mais profunda com as intenções de sentido expressas pelo entrevistado. Um exemplo desse tratamento analítico 
pode ser observado nas falas de dois bolsistas participantes da investigação, os sujeitos U3G e U3E, ambos da instituição U3. O Quadro 1 mostra um trecho das falas desses bolsistas.

Quadro 1: Exemplos de falas de participantes da pesquisa Bolsista U3G: Agora já estou habituado com a confusão que, às vezes, é uma sala de aula. Mas, assim, até pegar o ritmo. Agora, falar com o pessoal é tranquilo também, assim. A única questão mesmo é a parte da didática, que a gente vê um pouco mais pra frente, como trabalhar os conteúdos, para quê... Isso, eu não tenho, na verdade.

Bolsista U3E: Se eles não vão se surpreender por uma aula diferente hoje, eles não vão se surpreender no decorrer do ano, e, para tu não criares aquela bagunça na sala de aula, tu acabas não fazendo. Fonte: Ribeiro (2017)

A unitarização desses trechos com base nas novas ideias que as falas indicam e a reescrita a partir da compreensão do pesquisador são apresentadas no Quadro 2. Cada unidade de sentido indica um código a partir da representação do sujeito.

Quadro 2: Exemplos de unitarização e reescrita de fragmentos

\begin{tabular}{|l|l|}
\hline \multicolumn{1}{|c|}{ Unidades de sentido } & \multicolumn{1}{|c|}{ Reescrita } \\
\hline $\begin{array}{l}\text { U3G-1 Agora já estou habituado com a confusão } \\
\text { que, às vezes, é uma sala de aula. }\end{array}$ & $\begin{array}{l}\text { O bolsista identifica a sala de aula como um } \\
\text { ambiente eventualmente confuso, mas pôde } \\
\text { habituar-se com essa situação ao longo de sua } \\
\text { prática docente. }\end{array}$ \\
\hline U3G-2 Mas, assim, até pegar o ritmo. & $\begin{array}{l}\text { Até que se habitue com o ambiente de sala de aula, } \\
\text { o bolsista pode encontrar algumas dificuldades. }\end{array}$ \\
\hline $\begin{array}{l}\text { U3G-3 Agora, falar com o pessoal é tranquilo } \\
\text { também, assim. }\end{array}$ & $\begin{array}{l}\text { A comunicação com os estudantes pode ser feita de } \\
\text { forma tranquila; o bolsista não enfrenta dificuldades } \\
\text { nesse processo. }\end{array}$ \\
\hline $\begin{array}{l}\text { U3G-4 A única questão mesmo é a parte da } \\
\text { didática, que a gente vê um pouco mais pra frente. }\end{array}$ & $\begin{array}{l}\text { Há dificuldade em relação ao desenvolvimento do } \\
\text { conteúdo de Química, já que, durante a licenciatura, } \\
\text { essas disciplinas são desenvolvidas em momento } \\
\text { posterior à participação no Pibid. }\end{array}$ \\
\hline $\begin{array}{l}\text { U3G-5 Como trabalhar os conteúdos para, que isso } \\
\text { eu não tenho na verdade. }\end{array}$ & $\begin{array}{l}\text { O bolsista encontra dificuldades em desenvolver } \\
\text { uma proposta pedagógica para apresentar os } \\
\text { conteúdos de Química aos estudantes. }\end{array}$ \\
\hline $\begin{array}{l}\text { U3E-1 Se eles não vão se surpreender por uma aula } \\
\text { diferente hoje, eles não vão se surpreender no } \\
\text { decorrer do ano. }\end{array}$ & $\begin{array}{l}\text { Os estudantes operam em sala de aula com uma } \\
\text { postura de continuar um processo transmissivo de } \\
\text { ensino, ao qual já estão habituados. }\end{array}$ \\
\hline $\begin{array}{l}\text { U3E-2 Para tu não criares aquela bagunça na sala } \\
\text { de aula, tu acabas não fazendo. }\end{array}$ & $\begin{array}{l}\text { O professor termina por não propor práticas } \\
\text { pedagógicas diferentes das formas tradicionais, já } \\
\text { que isso modificaria o comportamento habitual da } \\
\text { turma em sala de aula. }\end{array}$ \\
\hline
\end{tabular}

Fonte: Ribeiro (2017)

A partir da interpretação dos fragmentos apresentados e da compreensão do sentido do que cada sujeito disse, é possível identificar palavras-chave para orientar o processo de análise, já com o objetivo de iniciar um processo de categorização. O Quadro 3 mostra as palavras-chave determinadas para cada unidade de sentido. 
Quadro 3: Determinação das palavras-chave

\begin{tabular}{|c|c|c|}
\hline Unidades de sentido & Reescrita & Palavras-chave \\
\hline $\begin{array}{l}\text { U3G-1 Agora já estou } \\
\text { habituado com a } \\
\text { confusão que, às vezes, } \\
\text { é uma sala de aula. }\end{array}$ & $\begin{array}{l}\text { O bolsista identifica a sala de aula } \\
\text { como um ambiente eventualmente } \\
\text { confuso, mas pôde habituar-se com } \\
\text { essa situação ao longo de sua prática } \\
\text { docente. }\end{array}$ & $\begin{array}{l}\text { Prática docente } \\
\text { Ambiente de sala de aula }\end{array}$ \\
\hline $\begin{array}{l}\text { U3G-2 Mas, assim, até } \\
\text { pegar o ritmo. }\end{array}$ & $\begin{array}{l}\text { Até que se habitue com o ambiente de } \\
\text { sala de aula, o bolsista pode encontrar } \\
\text { algumas dificuldades. }\end{array}$ & $\begin{array}{l}\text { Prática docente } \\
\text { Ambiente de sala de aula }\end{array}$ \\
\hline 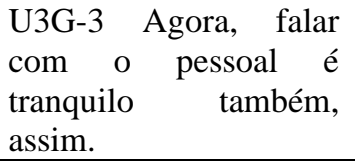 & $\begin{array}{l}\text { A comunicação com os estudantes } \\
\text { pode ser feita de forma tranquila; o } \\
\text { bolsista não enfrenta dificuldades } \\
\text { nesse processo. }\end{array}$ & $\begin{array}{l}\text { Prática docente } \\
\text { Comunicação com os estudantes }\end{array}$ \\
\hline $\begin{array}{l}\text { U3G-4 A única questão } \\
\text { mesmo é a parte da } \\
\text { didática, que a gente vê } \\
\text { um pouco mais pra } \\
\text { frente. }\end{array}$ & $\begin{array}{l}\text { Há dificuldade em relação ao } \\
\text { desenvolvimento do conteúdo de } \\
\text { Química, já que, durante a } \\
\text { licenciatura, essas disciplinas são } \\
\text { desenvolvidas em momento posterior } \\
\text { à participação no Pibid. }\end{array}$ & $\begin{array}{l}\text { Conteúdos de Química } \\
\text { Currículo da Licenciatura }\end{array}$ \\
\hline $\begin{array}{l}\text { U3G-5 Como trabalhar } \\
\text { os conteúdos, para } \\
\text { quê... Isso, eu não } \\
\text { tenho, na verdade. }\end{array}$ & $\begin{array}{l}\text { O bolsista encontra dificuldades em } \\
\text { desenvolver uma proposta pedagógica } \\
\text { para apresentar os conteúdos de } \\
\text { Química aos estudantes. }\end{array}$ & $\begin{array}{l}\text { Conteúdos de Química } \\
\text { Prática docente }\end{array}$ \\
\hline $\begin{array}{l}\text { U3E-1 Se eles não vão } \\
\text { se surpreender por uma } \\
\text { aula diferente hoje, eles } \\
\text { não vão se surpreender } \\
\text { no decorrer do ano. }\end{array}$ & $\begin{array}{l}\text { Os estudantes operam em sala de aula } \\
\text { com uma postura de continuar um } \\
\text { processo transmissivo de ensino, ao } \\
\text { qual já estão habituados. }\end{array}$ & $\begin{array}{l}\text { Prática docente } \\
\text { Ensino tradicional }\end{array}$ \\
\hline $\begin{array}{l}\text { U3E-2 Para tu não } \\
\text { criares aquela bagunça } \\
\text { na sala de aula, tu } \\
\text { acabas não fazendo. }\end{array}$ & $\begin{array}{l}\text { O professor termina por não propor } \\
\text { práticas pedagógicas diferentes das } \\
\text { formas tradicionais, já que isso } \\
\text { modificaria o comportamento habitual } \\
\text { da turma em sala de aula. }\end{array}$ & $\begin{array}{l}\text { Prática docente } \\
\text { Ensino tradicional }\end{array}$ \\
\hline
\end{tabular}

Fonte: Ribeiro (2017)

Após o estabelecimento das palavras-chave, o pesquisador pode propor um primeiro exercício de categorização. O Quadro 4 mostra a indicação de categorias iniciais para os trechos analisados.

Quadro 4: Categorias Iniciais

\begin{tabular}{|l|l|l|l|}
\hline Unidades de sentido & Reescrita & Palavras-chave & Categorias Iniciais \\
\hline $\begin{array}{l}\text { U3G-1 Agora já estou } \\
\text { habituado com a a } \\
\text { confusão que, às vezes, } \\
\text { é uma sala de aula. }\end{array}$ & $\begin{array}{l}\text { O bolsista identifica a } \\
\text { sala aula como um } \\
\text { ambiente eventualmente } \\
\text { confuso, mas pôde } \\
\text { habituar-se com essa } \\
\text { situação ao longo de sua } \\
\text { prática docente. }\end{array}$ & $\begin{array}{l}\text { Prática docente } \\
\text { Ambiente de sala de } \\
\text { aula }\end{array}$ & $\begin{array}{l}\text { Primeiros momentos de } \\
\text { docência dos bolsistas }\end{array}$ \\
\hline $\begin{array}{l}\text { U3G-2 Mas, assim, até } \\
\text { pegar o ritmo. }\end{array}$ & $\begin{array}{l}\text { Até habitue com } \\
\text { aula, o bolsista pode } \\
\text { ancontrar algumas } \\
\text { dificuldades. }\end{array}$ & $\begin{array}{l}\text { Ambiente de sala de } \\
\text { aula }\end{array}$ & $\begin{array}{l}\text { Primeiros momentos de } \\
\text { docência dos bolsistas }\end{array}$ \\
\hline
\end{tabular}




\begin{tabular}{|c|c|c|c|}
\hline $\begin{array}{l}\text { U3G-3 Agora, falar com } \\
\text { o pessoal é tranquilo } \\
\text { também, assim. }\end{array}$ & $\begin{array}{l}\text { A comunicação com os } \\
\text { estudantes pode ser feita } \\
\text { de forma tranquila; o } \\
\text { bolsista não enfrenta } \\
\text { dificuldades nesse } \\
\text { processo. }\end{array}$ & $\begin{array}{l}\text { Prática docente } \\
\text { Comunicação com os } \\
\text { estudantes }\end{array}$ & $\begin{array}{l}\text { Primeiros momentos de } \\
\text { docência dos bolsistas }\end{array}$ \\
\hline $\begin{array}{l}\text { U3G-4 A única questão } \\
\text { mesmo é a parte da } \\
\text { didática, que a gente vê } \\
\text { um pouco mais pra } \\
\text { frente. }\end{array}$ & $\begin{array}{lr}\text { Há dificuldade em } \\
\text { relação ao } \\
\text { desenvolvimento do } \\
\text { conteúdo de Química, já } \\
\text { que, durante a } \\
\text { licenciatura, essas } \\
\text { disciplinas rão } \\
\text { desenvolvidas em } \\
\text { momento posterior à } \\
\text { participação no Pibid. }\end{array}$ & $\begin{array}{l}\text { Conteúdos de Química } \\
\text { Currículo da } \\
\text { Licenciatura }\end{array}$ & $\begin{array}{l}\text { Os conteúdos de } \\
\text { Química para o Ensino } \\
\text { Médio }\end{array}$ \\
\hline $\begin{array}{l}\text { U3G-5 Como trabalhar } \\
\text { os conteúdos, para quê... } \\
\text { Isso, eu não tenho, na } \\
\text { verdade. }\end{array}$ & $\begin{array}{lr}\text { O bolsista encontra } \\
\text { dificuldades } \\
\text { desenvolver } \\
\text { proposta pedagógica } \\
\text { para apresentar os } \\
\text { conteúdos de Química } \\
\text { aos estudantes. }\end{array}$ & $\begin{array}{l}\text { Conteúdos de Química } \\
\text { Prática docente }\end{array}$ & $\begin{array}{l}\text { Primeiros momentos de } \\
\text { docência dos bolsistas }\end{array}$ \\
\hline $\begin{array}{l}\text { U3E-1 Se eles não vão } \\
\text { se surpreender por uma } \\
\text { aula diferente hoje, eles } \\
\text { não vão se surpreender } \\
\text { no decorrer do ano. }\end{array}$ & $\begin{array}{l}\text { Os estudantes operam } \\
\text { em sala de aula com } \\
\text { uma postura de } \\
\text { continuar um processo } \\
\text { transmissivo de ensino, } \\
\text { ao qual já estão } \\
\text { habituados. }\end{array}$ & $\begin{array}{l}\text { Prática docente } \\
\text { Ensino tradicional }\end{array}$ & $\begin{array}{l}\text { Primeiros momentos de } \\
\text { docência dos bolsistas }\end{array}$ \\
\hline $\begin{array}{l}\text { U3E-2 Para tu não } \\
\text { criares aquela bagunça } \\
\text { na sala de aula, tu } \\
\text { acabas não fazendo. }\end{array}$ & $\begin{array}{l}\text { O professor termina por } \\
\text { não propor práticas } \\
\text { pedagógicas diferentes } \\
\text { das formas tradicionais, } \\
\text { já que isso modificaria o } \\
\text { comportamento habitual } \\
\text { da turma em sala de } \\
\text { aula. }\end{array}$ & $\begin{array}{l}\text { Prática docente } \\
\text { Ensino tradicional }\end{array}$ & $\begin{array}{l}\text { Primeiros momentos de } \\
\text { docência dos bolsistas }\end{array}$ \\
\hline
\end{tabular}

Fonte: Ribeiro (2017)

A partir desse primeiro resultado de categorização, o pesquisador desenvolve a análise com vistas a observar convergências entre as categorias iniciais, até que emerjam as categorias finais que orientarão a escrita do metatexto. Um exercício completo de Análise Textual Discursiva pode ser observado em Ribeiro e Ramos (2019a).

\section{Resultados da Pesquisa}

A investigação que norteou este artigo buscou construir respostas à pergunta: de que modo a Análise Textual Discursiva pode contribuir para compreender o impacto na formação e na prática docente de professores de Química, no âmbito do Pibid, na forma de uma comunidade de prática? 
A análise das entrevistas dos grupos de bolsistas de iniciação à docência e as respostas dos professores egressos ao questionário enviado fizeram emergir três categorias, das quais duas são analisadas neste artigo: O papel do Pibid na formação de professores e A prática docente originada a partir da participação no Pibid.

\subsection{O papel do Pibid na formação de professores}

Esta categoria emergiu da análise de depoimentos obtidos em dois momentos da investigação: entrevistas com bolsistas e questionários respondidos por licenciados egressos.

Os bolsistas, de modo espontâneo, contribuíram com sua percepção dos fatos que vivenciam no convívio semanal com seus coordenadores e supervisores, bem como com os estudantes da escola básica na qual desenvolvem o projeto. Esses bolsistas já indicam compreensão sobre sua formação como professores, relacionando-a com a participação no Pibid. O segundo campo de obtenção de dados foi o de questionários enviados a licenciados egressos do Pibid que atuam em escolas da Educação Básica. Esses novos professores de Química trazem em sua formação as concepções construídas ao longo da participação no Pibid.

Durante o tratamento por ATD, surgiram duas subcategorias, a seguir analisadas.

\subsubsection{A influência dos coordenadores do Pibid na formação de professores}

Os subprojetos de Química investigados apresentam realidades e práticas diferentes. Segundo os depoimentos dos egressos, os encontros dos subprojetos têm o objetivo de permitir discussões e preparação de atividades.

O professor egresso P21 afirma que as atividades realizadas em sua participação no Pibid eram importantes no sentido de deixar os bolsistas confiantes de que suas investidas na escola teriam bons resultados. Convém compreender, porém, que os períodos de participação no Pibid foram diferentes para os licenciados e para os atuais bolsistas. Em geral, os egressos ingressaram no Pibid em um edital anterior ao dos bolsistas que participaram da investigação.

Os relatos analisados revelam a natureza colaborativa da formação de professores por meio da participação no Pibid. O trabalho feito no grupo do Pibid faz emergirem resultados mais consistentes do que surgiriam em ações individuais, embora não haja certeza da qualidade formal desses resultados. 
Então, as discussões e argumentações ocorridas nas reuniões do subprojeto que podem amadurecer aquilo que foi vivenciado pelos bolsistas transformam-se, por meio do diálogo, em real aprendizagem. Ramos e Moraes afirmam que:

\begin{abstract}
Nesse sentido, o diálogo possibilita a confrontação com o diferente, e diferentes níveis de complexidade. Por isso, os interlocutores vão reconstruindo sentidos em relação aos fenômenos e conceitos envolvidos na interação com os outros, seja por imitação, por confrontação, por colaboração ou pela controvérsia. É desse modo que, mesmo de forma inconsciente, enquanto falam ou escutam, os alunos revisam seus entendimentos sobre o objeto de estudo e reelaboram seus conceitos, reconstroem seus conhecimentos (RAMOS; MORAES, 2009, p. 5).
\end{abstract}

Considerando-se as ações teóricas que envolvem os subprojetos de Química analisados, pode-se observar outra diferença. Bolsistas das IES U3 e U4 informam que, em suas reuniões, são preparados planos de aula que, entretanto, nunca são de fato aplicados. $\mathrm{Na}$ instituição U4, nem sequer havia encontro regular dos licenciandos durante a semana, sendo reservado, em algumas ocasiões, o sábado para essa reunião. Isso acontecia, entre outros fatores, porque alguns bolsistas à época trabalhavam durante a semana ou moravam em local distante da universidade, o que dificultava a chegada em determinados horários estabelecidos pelo coordenador. Nessa instituição, não havia a produção de materiais em um período da existência do subprojeto, apenas a elaboração do plano de aula, como relata o estudante $\mathrm{U}_{4} \mathrm{~A}^{4}$ quando afirma: "No início, a gente não fez nenhum material para trabalhar com eles, nós fazíamos planos de aula. O horário de encontro dos pibidianos varia. Eventualmente, é aos sábados”. Essa situação também é destacada pelo bolsista U3F. Em sua instituição, era comum, com o coordenador de área que foi substituído, que os licenciandos apenas fizessem observações de aula e que, depois, tentassem reproduzir a aula assistida na elaboração de um plano de aula.

Esse sujeito revela uma questão que se reproduz em outros depoimentos de participantes vinculados a algumas instituições: a ausência de docência por parte dos licenciandos participantes do Pibid. A iniciação à docência, objetivo central do Programa, não é realizada de forma ostensiva em alguns dos projetos investigados, segundo a manifestação de bolsistas, sendo deixado para as disciplinas de estágio o começo da vida docente desses licenciandos.

Outra dificuldade encontrada nos grupos são os primeiros contatos com a docência. Esse contato acontece, quase sempre, nas disciplinas de estágio. Nos subprojetos de Química do Pibid, como visto, essa prática não é frequente. Mesmo assim, a participação

\footnotetext{
${ }^{4}$ As falas dos sujeitos participantes da pesquisa estão grafadas em itálico para diferenciá-las das falas dos teóricos que dão suporte ao texto.
} 
no Pibid mostra vantagens aos licenciandos quando estes realizam o estágio e chegam à escola. O bolsista U7D relata:

\begin{abstract}
Aqui na [cita instituição] tem os professores do estágio aqui na [cita instituição], que eles fizeram um comentário uma vez que foi muito interessante. O estagiário, quando ele passou pelo Pibid, ele é diferente do estagiário que só teve as cadeiras teóricas. Então, ele tem... A ideia dele, a cabeça dele é diferente, então, ele enxerga a sala de aula de outra maneira, [diferentemente de] alguém que vai pegar a sala de aula pela primeira vez lá no final do curso e depois tem que se deparar com a realidade, tomar aquele baque lá fora (Bolsista U7D, 2015).
\end{abstract}

Entretanto, a realidade encontrada na sala de aula é distante da concepção que o bolsista traz de sua formação. A tentativa de execução das aulas elaboradas e as relações com os estudantes da escola colocam-se entre o planejado e o executado. O bolsista U1A afirma: "Por exemplo, eu preparo uma aula no estágio, vamos dizer, lá, eu imagino que minha aula vai demorar três aulas. Eu vou preparar um projeto, miniprojeto, que vai demorar umas três aulas. Eu quero aplicar na aula normal. Eu não tenho como fazer isso”. Com esse depoimento, pode-se perceber que a chegada à sala de aula se dá por meio das disciplinas de estágio, mesmo que o bolsista participe do Pibid. Essa concepção é compartilhada pelo licenciado P32 quando afirma que é bastante diferente a situação de entrar em sala de aula durante a participação no Pibid, no estágio e quando se é o professor titular da turma, função que exerce atualmente. Segundo afirma P32, o professor pode fazer suas próprias escolhas pedagógicas, enquanto o bolsista segue as combinações feitas em seu grupo. Além disso, o professor é mais respeitado pelos estudantes do que o bolsista.

\title{
4.1.2 A participação no Pibid como processo na formação de novos professores de Química
}

Algumas das imagens e experiências que o estudante guarda da época em que cursava o Ensino Médio podem traduzir-se em concepções ou representações mentais no momento de sua formação na universidade. O ingresso na Licenciatura em Química e, em especial, a participação no Pibid permitem que o perfil de professor em formação adquira novos contornos. A formalização da preparação de um novo professor de Química decorre de algumas instâncias, como as disciplinas de cunho pedagógico, os estágios e a participação no Pibid. Em uma primeira análise, os bolsistas têm dificuldades em identificar se algumas ações que relatam e aquilo de que se apropriaram em termos de prática pedagógica se deram durante os estágios obrigatórios ou no Pibid. 
É fato conhecido a falta de professores de Química no Brasil. Além da falta normal de professores, licenciandos participantes do Pibid também assumem a vaga de professores em escolas onde não há interessados que sejam autorizados a assumi-las. O bolsista U3G afirma: "Em 2005, eu dei aula em uma escola, mesmo sem estar formado nem nada, porque ninguém queria dar naquela escola, estava faltando professor".

Porém, tão preocupante quanto essa situação é a identificação de que professores atuam em componentes curriculares diferentes de sua área de formação. Essa é uma realidade que também é percebida na escola. O bolsista U1A, ao ser questionado sobre como havia sido seu primeiro contato com a preparação para a docência na escola, disse que "a observação era na aula de Química, mas o professor era de Biologia. Então, foi muito ruim".

A falta de professores de Química antecipa o início da carreira profissional de licenciandos que já demonstram interesse pela docência, mesmo que em tempo ainda distante da conclusão de seus cursos. Esses licenciandos, então, já em atividade docente, são levados à sala de aula antes de participarem do Pibid. Em uma análise do perfil desses licenciandos, nota-se satisfação pelo que fazem na escola. O bolsista U4E relata a origem de seu desejo de iniciar a atividade docente, contrastando o caráter de professor com as condições do trabalho na indústria:

\begin{abstract}
[...] a educação do meu aluno vai depender muito de mim, do meu querer ou não. Na parte da indústria, eu tinha que fazer as coisas erradas, que eu não queria, porque tinha gente acima de mim, então, foi por isso que eu desisti e quero passar para a educação. E outras coisas assim, os meus princípios pessoais, tipo social, a parte social, que eи quero trabalhar, pelos meus princípios mais também (Bolsista U4E, 2015).
\end{abstract}

Os bolsistas, ao apresentarem-se na escola onde desenvolverão suas atividades, entram em contato com a realidade desse ambiente e com as pessoas que lá trabalham ou estudam. Percebe-se aí que a recepção dos bolsistas do Pibid nas escolas nem sempre ocorre de forma agradável. Algumas resistências impõem-se aos licenciandos, visto que levam propostas que podem romper com práticas tradicionais, historicamente mais cômodas aos professores das escolas. O licenciado P73, por exemplo, afirma que busca sempre fazer relações do conteúdo com o cotidiano dos estudantes: "Trabalho na EJA, então, a preocupação com o ensino é evidente, pois [os estudantes] apresentam dificuldades de aprendizagem". As diferentes realidades sociais e educacionais dos estudantes na escola podem apresentar-se como limitadores das ações dos bolsistas, uma vez que estes ainda não estão acostumados a trabalhar com realidades diferentes daquelas 
que vivenciaram em seu tempo de estudantes na Educação Básica e mesmo na Licenciatura em Química.

Nesse contexto, os relatos dos professores egressos podem apresentar contradições em relação ao objetivo do trabalho do professor na escola. Enquanto o professor P43 afirma, por premissa, que "o ensino de Química implica a compreensão das transformações químicas que ocorrem no mundo físico", o licenciado P42 refere que o objetivo do ensino de Química é proporcionar o "desenvolvimento de pessoas com uma visão crítica sobre as questões da sociedade". Dessa forma, as dificuldades criadas pela falta da docência orientada são as que mais preocupam os bolsistas.

\subsection{A prática de docência a partir da participação no Pibid}

A participação de licenciandos como bolsistas do Pibid tem influenciado tanto a decisão desses bolsistas de permanecerem na licenciatura, quanto a sua prática de docência. Isso ocorre em dois momentos: durante a participação no Pibid e posteriormente, quando se encerra sua graduação e eles se inserem no mundo do trabalho, assumindo postos em escolas de Educação Básica.

\subsubsection{As concepções dos bolsistas sobre a prática profissional}

O Pibid é decisivo na opção dos bolsistas por realmente tornarem-se professores. Mesmo que os bolsistas de iniciação à docência identifiquem dificuldades na profissão de professor, a participação no Pibid, por meio das relações que acontecem com os estudantes, é definidora para essa profissão.

Os bolsistas reconhecem dificuldades na profissão de professor. O bolsista $\mathrm{U} 3 \mathrm{H}$ percebe dificuldades ao observar as aulas durante uma ação do Pibid. O bolsista diz: "Na verdade, a gente tem que, além de observar, nós precisamos anotar tudo o que se passa dentro da sala de aula, então, automaticamente, você vê a dificuldade do professor e a dificuldade dos estudantes em relação ao conhecimento”. Esse relato é comum a outros licenciandos, ao afirmarem que há muitas dificuldades nas relações entre os professores e os estudantes na Educação Básica.

O desejo de ser professor de Química surge apenas ao longo do trabalho no Pibid, não sendo prévio nos bolsistas. Com algumas exceções, como o bolsista U4C, que afirma sempre ter desejado ser professor de Química, a maior parte dos bolsistas constrói o desejo por essa profissão durante as atividades no Programa. Há, inclusive, a ideia de que a 
profissão de professor é uma alternativa para quem não tem outras opções profissionais. $\mathrm{O}$ licenciando U3I concorda com essa afirmação feita pelo pesquisador, o que está transcrito no diálogo abaixo: "Pesquisador - Vocês acham que é uma profissão para quem não achou outra coisa para fazer? Bolsista U3I - [Para] Muitos [professores], sim”.

O desejo de ser professor de Química está presente nas manifestações dos bolsistas como algo que se constituiu no âmbito do Pibid. Todos os bolsistas do subprojeto Química da instituição U4 indicam que, após o ingresso no Pibid, mudaram suas concepções e que, hoje, todos desejam ser professores de Química. É comum entre os bolsistas a manifestação de que a profissão docente não era sua intenção inicial. A licencianda U2E afirma que, inicialmente, pensava: “Deus me livre ser professora!”. Nesse subprojeto, nenhum dos integrantes tinha intenção de ser professor antes de ingressar no Pibid.

Alguns bolsistas tinham, de início, o desejo de trabalhar na indústria Química em paralelo, ou mesmo de forma única, com a licenciatura. Os relatos surgidos mostram que o Pibid fez com que essa concepção fosse modificada e que a Licenciatura em Química se tornasse a prioridade desses participantes.

A opção pela Licenciatura em Química em substituição à indústria química está presente no depoimento de diversos bolsistas. O licenciando U3B relata que, após seis anos na indústria química, resolveu optar pela Licenciatura em Química porque percebeu que, na escola, pode fazer a diferença para alguns sujeitos: os estudantes. A mesma situação emerge do depoimento do bolsista U4E, que afirma ter feito a opção por "um curso mais calmo: a Licenciatura em Química”, em comparação ao curso de Química Industrial.

Os bolsistas de iniciação à docência de todas as IES investigadas apresentam uma condição em comum. Todos realizaram seus estudos no Ensino Médio em escolas públicas estaduais no estado do Rio Grande do Sul, com exceção de um licenciando, que o fez em escola pública do estado de Santa Catarina. Essa condição faz com que todos os bolsistas expressem sua intenção de, após concluírem a Licenciatura em Química, ingressarem como professores na rede pública estadual. Essa demonstração de interesse não exclui outras opções, como a de trabalho na rede privada ou no Ensino Superior, ou mesmo a de continuação dos estudos na pós-graduação. Essas opções são claras, por exemplo, nas manifestações dos licenciandos U4A, U2A, U1A e U3G. O bolsista U4A relata sua preferência por trabalho no Ensino Superior, embora não descarte as opções das escolas públicas municipais ou estaduais. Afirma U4A: "Penso em um futuro em universidades, mais escola estadual ou municipal". Porém, a facilidade de obter contrato provisório de professor nas escolas estaduais aumenta o interesse dos bolsistas por esse sistema de 
ensino. Segundo o bolsista U3G: "A princípio, o ideal seria o município aqui na região, só que eu sei que é mais fácil pegar no estado, a princípio”. Já o bolsista U1A não descarta a opção de continuação dos estudos ao dizer: "A gente queria fazer voltado para isso, não é? Para a educação, Mestrado em educação".

A opção entre escola pública estadual ou municipal não é legítima para os bolsistas. A habilitação que lhes será concedida pela sua graduação permite apenas sua atividade no Ensino Médio, nível de estudo que é oferecido somente, com poucas exceções, pela escola pública estadual. Essa questão é lembrada pelo licenciando U2A, ao afirmar: "[...] e, com certeza, na rede pública estadual, porque nossa formação é para Ensino Médio, mas quem dá aula para as [séries] finais é escola municipal”.

O bolsista U4D identifica as diferenças de exigência profissional para o professor entre escolas públicas e privadas quando afirma:

\begin{abstract}
Eu não teria problema em dar aula na escola particular ou pública. Claro, nas duas, mas mais na escola pública, tanto faz estadual, municipal ou federal, é uma estabilidade. Eu penso que é uma forma de ficar mais tranquilo, mas eu acho que, em relação a trabalhar em uma escola privada, não vejo nenhum problema. Eu acho que, na escola privada, tu tens que dar mais resultados, então, tu tens, eu acho que tu trabalhas mais, é exigido mais de ti. Também não vejo isso como problema (Bolsista U4D, 2015).
\end{abstract}

Fato comum nos depoimentos é a necessidade de trabalhar. Os bolsistas de iniciação à docência relatam que, mesmo que decidam pela continuidade dos estudos, precisarão ingressar no mercado de trabalho, preferencialmente exercendo a docência. O bolsista U2C refere: "Quero me formar e entrar no mercado de trabalho. Primeiro um contrato [na escola pública estadual]". Outro licenciando da mesma instituição concorda com essa necessidade, que parece comum a todos os licenciandos desse grupo. O bolsista U2D afirma: "É uma necessidade me formar em fevereiro e já ingressar no mercado de trabalho no ano que vem e conciliar também".

A opção de continuar os estudos, ao lado da necessidade de trabalhar, também é comentada pelos licenciandos.

\title{
4.2.2 Atividades docentes dos bolsistas nas escolas
}

O Pibid tem apresentado resultados positivos em relação à formação de professores. Algumas das ações julgadas importantes são o encontro e a realização de atividades com bolsistas de outras áreas (subprojetos), em propostas interdisciplinares. Essas práticas têm sido descritas em artigos de autoria dos próprios bolsistas com supervisores e coordenadores (DUBOW; SILVA-JÚNIOR; FERREIRA, 2014; GODINHO et al., 2013). 
Esses artigos tratam de temáticas relacionadas às áreas e ao cotidiano da comunidade na qual a escola está inserida. Tais produções contribuem para mostrar a todos os envolvidos, em especial aos bolsistas e supervisores, a importância da pesquisa para a compreensão de suas práticas (ALARCÃO, 2001; MALDANER, 2013; SCHÖN, 1992) e para a qualificação dessas práticas. Embora as estratégias interdisciplinares possam contribuir para a aprendizagem dos estudantes na compreensão da realidade complexa, podem não ser suficientes para promover a compreensão de todo o grupo de estudantes.

Entre as dificuldades, uma que se destaca é de natureza operacional, pois se trata das limitações dos bolsistas da Química para encontrarem-se com bolsistas de outras áreas. Outra dificuldade consiste no próprio planejamento de atividades, que, em geral, ficam restritas ao conhecimento químico. Desse modo, os estudantes têm apresentado dificuldades para compreender o significado de interdisciplinaridade, o que está associado à falta de compreensão dos próprios professores. O que ocorre, às vezes, é o coordenador ou o supervisor levar para discussão algo que ele encontrou ou pensou.

Na verdade, é assim: o professor da escola te procura, seja da disciplina que for. Por exemplo, vem alguém da Matemática e vem até ti pra pedir um subsídio pra uma atividade nas duas disciplinas. Aí tu corres atrás, pesquisas com o teu grupo, os bolsistas, procuras alguma coisa e pedes ajuda à supervisora que está na escola. Aí a supervisora traz alguma ideia, algum trabalho, aí tu pesquisas sobre aquilo e trabalhas aquilo na escola, desenvolves (Bolsista U2A, 2015).

Nos relatos dos licenciandos, evidencia-se que essas ações não usam, de fato, os pressupostos da interdisciplinaridade (FAZENDA, 2008), simplesmente reúnem professores de diferentes componentes curriculares para fazer algo juntos ou um mesmo professor trabalha com conteúdo de outras disciplinas.

Um exemplo do modo como os bolsistas trabalham questões interdisciplinares pode ser observado no enunciado do licenciando U2B: "Ali na escola em que eu estou trabalhando agora, a gente fez os aulões. A gente pegava um tema de outra disciplina, eu, por exemplo, peguei Português, trabalhei o conteúdo de Português junto com a Química”.

No mesmo sentido desse depoimento, o licenciando U2A relata que, em sua escola, foi escolhido um tema para que fosse trabalhado por todos os bolsistas de cada subprojeto que atendia a escola. Na instituição U2, por exemplo, ocorre, duas vezes por ano, um evento interno dos subprojetos do Pibid. Entretanto, não são programadas ações interdisciplinares para serem levadas às escolas.

Nessa subcategoria, há, portanto, afirmações reveladoras de atividades nas quais os bolsistas estavam efetivamente inseridos. As atividades são designadas, em princípio, pelos coordenadores e, em última análise, pelo supervisor na escola. Entretanto, bolsistas de 
iniciação à docência relatam que nem sempre são orientados a realizarem ações relacionadas à docência em sala de aula. Nessas escolas, os bolsistas do Pibid são encarregados de ficar à disposição dos estudantes no contraturno das aulas para resolução de listas de exercícios e para plantões de dúvidas. Assim, exercem função de monitores, mas não de professores, não estabelecendo função de docência. Em outras escolas, porém, os estudantes bolsistas são orientados a desenvolver oficinas, assumindo a docência em sala de aula. Os temas trabalhados nessas oficinas são indicados pelos supervisores e não necessitam estar associados aos conteúdos trabalhados em sala de aula pelo professor da turma. Há relatos de oficinas sobre drogas, álcool e tabagismo. Em outros subprojetos de Química, podem ser observadas atividades com jogos educativos que utilizam a tabela periódica e medicamentos como temas. Além dos jogos, os bolsistas também desenvolvem outros tipos de materiais didáticos sobre drogas e álcool para trabalhar nas oficinas.

A elaboração de materiais didáticos e estratégias de modelagem também ocorre de forma interdisciplinar em algumas escolas. Os relatos apresentados permitem perceber que as escolas que recebem os bolsistas do Pibid os usam como meio para resolver questões pontuais na aprendizagem de Química, tendo algum afastamento do processo de ensino convencional. Faz-se a opção por resolver questões que interfiram diretamente na nota do estudante na escola, não importando a real apropriação dos conceitos por parte dos estudantes.

O que parece ter a maior proximidade com ações de docência são as aulas que ocorrem no laboratório de Química ou de Ciências na escola. Os bolsistas são solicitados a prepararem essas aulas e, na maioria dos casos, a atuarem como auxiliares nas aulas. Essa situação é relatada por bolsistas de todas as IES investigadas. Sobre isso, o bolsista U2F afirma: “[...] teve o primeiro grupo do Pibid, que era a professora que dava a aula teórica e a gente dava laboratório, a gente introduzia as práticas". Esse relato traz duas revelações importantes. Inicialmente, há a informação de que as aulas preparadas no laboratório pelos bolsistas são complementares às aulas desenvolvidas pela professora da turma.

A mesma situação é encontrada no relato do bolsista U3E, de outra instituição, em relação à qual se pode concluir que a professora da escola coordena as ações para que os bolsistas possam assumir a aula prática no laboratório. Entretanto, as condições em que essas aulas se desenvolvem não são as mais adequadas. A falta de reagentes no laboratório e a falta de jaleco para os estudantes promovem dificuldades para que as aulas aconteçam. Diz o bolsista U3F: "e como normalmente os estudantes não têm o jaleco e não tem nada 
na escola, nós temos que fazer tipo uma aula demonstrativa [...] Então, eles nunca fazem aula, ou é o professor ou é nós, do Pibid".

Por fim, compreende-se que as escolas onde os bolsistas atuavam apresentavam algumas fragilidades estruturais e pedagógicas.

\subsubsection{Os desafios da prática de docência dos bolsistas participantes do Pibid}

A análise das entrevistas mostrou que as ações desenvolvidas pelos bolsistas nas escolas surgem em reuniões nos subprojetos, sendo concebidas pelos coordenadores desses subprojetos. Nessas reuniões, coordenadores e bolsistas realizam atividades semanais na escola a partir da escolha de temas desenvolvidos ao longo do semestre. Esse trabalho ocorre em grupos, e as temáticas escolhidas são executadas diretamente pelo subprojeto ou em ações interdisciplinares na escola. Outra forma de definir os temas a serem trabalhados na escola é pela análise da emergência das necessidades e desejos da comunidade na qual a escola está inserida. Inicialmente, os bolsistas levantam esses aspectos na comunidade e depois realizam estudos com seus coordenadores para que possam, eles mesmos, apropriarse dos conteúdos que serão trabalhados na escola.

Em movimento de oposição a essas práticas de construção pedagógica, pode-se perceber o uso dos bolsistas do Pibid como mão de obra para preparação de aulas e de materiais, não cabendo a eles a aplicação desses materiais nas aulas da escola. Cabem aos bolsistas a preparação das aulas e a organização do espaço após as aulas. Nos relatos de alguns bolsistas de iniciação à docência, percebe-se que esses participantes puderam oferecer uma disciplina opcional sobre experimentação no contraturno escolar. Essa disciplina não recebia avaliação oficial, sendo aproveitada para a apropriação dos conceitos teóricos trabalhados em sala de aula pelo professor. Nessa disciplina, os bolsistas podiam elaborar os planos pedagógicos e colocá-los em prática, sob a orientação de seu supervisor e do professor da turma.

Embora os relatos dos bolsistas sejam de que não assumam efetivamente as aulas na escola, a participação no Pibid revela outras situações importantes. Nos processos de observação desenvolvidos pelos licenciandos, podem ser encontrados relatos sobre o desenvolvimento de aulas conteudistas e de cunho transmissivo, o que remete que essa crítica e que a necessidade de novas propostas pedagógicas é desenvolvida nos encontros dos grupos do Pibid. Assim, os bolsistas percebem a necessidade de mudança das estratégias conteudistas para outras que permitam o protagonismo dos estudantes da escola. 
Os bolsistas conseguem, em seus enunciados, falar das dificuldades encontradas pelos professores durante suas aulas. Os relatos abordam desde dificuldades com a disciplina dos estudantes em sala de aula até dificuldades estruturais na própria escola. Nessas questões, justifica-se a participação dos licenciandos no Pibid em função de reconhecer a realidade escolar, tornando possível que os bolsistas de iniciação à docência reconheçam as dificuldades a que estarão expostos quando iniciarem na profissão. Nesse contexto, as atividades dos bolsistas concentram-se em apoiar a professora da escola em conteúdos e estratégias escolhidos por ela.

Essas questões relatadas promovem um receio dos bolsistas em iniciar o processo de docência. Há um temor em assumir a turma sozinhos. A bolsista U4C, iniciante no Pibid, diz:

A gente está no segundo semestre, mas eu estou pensando em quando tiver que
ir para a aula. Algo que me deixa assustada, até por eu não ter a experiência
em ir para a sala de aula assim, frente a frente com os estudantes, é que nos dias
de hoje a forma da escola, assim, os estudantes, está bem complicado, não é?
Tem escolas que a gente vê falarem horrores, assim, aí tu ficas pensando: "ah,
vou lá, talvez dar a minha primeira aula, vou sair, sei lá, correndo da sala de
aula ou vou ter que levar um segurança junto comigo", sabe? (Bolsista U4C,
2015).

O domínio dos conteúdos a ensinar também se coloca como um fator de ameaça aos bolsistas. Há a clara ideia de que o professor deve saber todo o conteúdo a trabalhar e também deve saber responder todas as perguntas feitas pelos estudantes. O relato do bolsista U1B é nesse sentido, quando diz: “É que, tipo, um professor está sempre estudando, não é? Está sempre, tipo, como a gente trabalha, assim, a gente não tem como ficar, entendeu? A gente não tem muito domínio da matéria”. No relato, percebe-se quase uma desistência do bolsista em iniciar o processo de docência, ao menos de forma individual.

Essas dificuldades não são exclusivas dos bolsistas dessa IES. Nos relatos de bolsistas de todas as IES investigadas, essa situação está presente, como afirma o bolsista U3G:

[...] eи acho que eu teria um pouco de dificuldade em saber, assim, como o conteúdo no caso que eu iria trabalhar. Agora já estou habituado com a confusão que às vezes é uma sala de aula, mas assim, até pegar o ritmo. Agora, falar com o pessoal é tranquilo também, assim. A única questão mesmo é a parte da didática, que a gente vê um pouco mais pra frente, como trabalhar os conteúdos, que isso eu não tenho, na verdade (Bolsista U3G, 2015).

A expectativa de, avançando nos estudos na Licenciatura em Química, adquirir confiança a ponto de superar essas dificuldades também é constante nos depoimentos. Os 
bolsistas de iniciação à docência entregam aos estudos na universidade a capacidade de apropriarem-se dos conteúdos que deverão ensinar na escola.

Contrapondo-se a esses relatos, outro bolsista reconhece que o professor pode estar em sala de aula sem saber todas as respostas, ou seja: "Se for alguma coisa que eu não souber responder na hora, o que que eu penso? Eu não vou saber responder agora, mas eu vou pesquisar, vou entender o assunto e vou te trazer a resposta na próxima aula." (Bolsista U4B, 2015). Assim, as dificuldades encontradas diminuem, e o desejo de docência aumenta.

Dessa forma, o Pibid apresenta-se como importante programa de formação de professores, uma vez que municia os bolsistas com práticas necessárias para o exercício da docência. Entretanto, nesse espaço de convivência, é relevante que os processos de formação de professores também exponham os bolsistas a situações que possam gerar conflito, como forma de preparação do perfil docente dos novos professores. Concorda-se com Pena, Silveira e Guilardi (2008) quando dizem que, "para minimizar essas insatisfações, é relevante que os cursos de formação e os formadores de docentes considerem os conflitos vividos pelos professores novatos, durante as formações iniciais e continuadas".

O Pibid possibilita ao bolsista a sensação de docência. Essa sensação decorre da necessidade de tomada de decisões em alguns momentos durante as atividades, mesmo que estas sejam preparadas e discutidas no grupo do subprojeto. Desse contexto, surge a competência do desenvolvimento da autonomia, importante para a construção do perfil profissional de um professor.

Também com esse objetivo, os primeiros contatos com os estudantes e com a realidade escolar acontecem em movimentos proporcionados pelo Pibid. Esses procedimentos iniciais contribuem para a diminuição do medo dos bolsistas do primeiro contato com os estudantes em sala de aula. Segundo a bolsista U2C: "Parece que, quanto mais vezes a gente entra em sala de aula e vai fazendo atividade com os estudantes, eu, parece que eu estou me sentindo mais à vontade”. Assim, é claro o sinal de que o Pibid estimula o gosto pela docência, estimulando a vontade dos bolsistas de entrar em sala de aula. 


\section{Considerações finais desta investigação}

A Análise Textual Discursiva mostrou-se potente metodologia de tratamento de informações nesta pesquisa qualitativa. A imersão do pesquisador no texto dos participantes que ocorre por parte do pesquisador permite que ele compreenda as intenções de quem respondeu à entrevista. A desconstrução e reconstrução do texto mostram um ressurgir de ideias na forma de uma nova compreensão.

Em relação aos achados na investigação, o Pibid constitui-se em uma das mais poderosas políticas públicas de formação de professores promovidas pelo Governo Federal do Brasil. A participação dos bolsistas em atividades na escola revela aos licenciandos, desde o início do curso, a realidade escolar, incluindo tanto as dificuldades enfrentadas pelos professores e estudantes quanto a satisfação dos contatos iniciais com estudantes em sala de aula e na escola.

Nos relatos dos bolsistas de iniciação à docência analisados, é notória a intenção de ingresso na profissão de professor devido à participação no Pibid. Assim, a partir dos dados analisados, é possível concluir que, nas instituições investigadas, o Pibid: contribui para modificar concepções pedagógicas dos envolvidos das IES (bolsistas de iniciação à docência e coordenadores de área) e das escolas da Educação Básica (professores, supervisores e estudantes); aumenta a permanência dos bolsistas na licenciatura; influi de modo relevante na decisão de ingresso dos bolsistas na profissão docente; aumenta o interesse dos licenciandos em atuar em escolas públicas; melhora a forma como os bolsistas são recebidos na escola onde atuam; provoca modificações relevantes na prática de professores que já exercem a docência nas escolas; e fortalece os cursos de Licenciatura em Química, contribuindo para introduzir inovações em seus currículos.

A entrada em sala de aula desde o início do curso mostra-se necessária para o desenvolvimento da confiança dos licenciandos, conferindo-lhes convicção de que essa deva ser sua opção profissional. Embora os estágios sejam os principais contextos de prática dos cursos de licenciatura, a investigação revela que alguns subprojetos atuam de forma a não proporcionar o imediato acesso à docência aos bolsistas, o que decorre das concepções, principalmente, de seus coordenadores de área e supervisores. Isso mostra a necessidade de um aperfeiçoamento do Programa em relação à avaliação dos processos e ao acompanhamento dos grupos nas IES.

Uma das teses defendidas nesta investigação é a de que o Pibid tem se revelado como decisivo para a manutenção dos bolsistas no curso de Licenciatura em Química e até 
mesmo para o ingresso definitivo na profissão docente, um dos objetivos do Programa, expresso na Portaria 96/2013 (BRASIL, 2013b). Outra tese é a de que os professores das escolas que participam do Pibid, em geral, se beneficiam com o Programa e se mostram interessados em atuar na escola pública, mantendo ações de formação continuada.

Pela análise dos dados obtidos na investigação, defende-se também a tese de que as reuniões dos subprojetos do Pibid e as relações entre os sujeitos envolvidos têm forte aproximação das características de uma comunidade de prática, segundo os pressupostos estabelecidos por Wenger (1998). O grupo de bolsistas de iniciação à docência, os professores supervisores e o coordenador de área são os membros dessa comunidade; a realização das atividades discutidas, preparadas e avaliadas pelo grupo estabelece a prática dessa comunidade; e a formação inicial e continuada de professores forma o domínio da comunidade de prática em que se estabelece o subprojeto do Pibid. Nesse contexto, os subprojetos do Pibid possuem características organizacionais que permitem identificá-los como uma comunidade de prática, envolvendo participação, engajamento, objetivos comuns, prática compartilhada e trabalho colaborativo.

Finalizando, pensa-se ser importante uma maior quantidade de estudos que abordem a organização dos subprojetos do Pibid na forma de uma comunidade de prática, visto que, como justificado neste artigo, essa forma de trabalho tem forte relevância nos resultados alcançados pelos subprojetos do Pibid aqui investigados.

\section{Referências}

ALARCÃO, I. A escola reflexiva. In: ALARCÃO, I. (org.). Escola reflexiva e nova racionalidade. Porto Alegre: Artmed, 2001.

ANJINOVICH, Rebeca; CAPPELLETTI, Graciela. El lugar de la práctica en la formación docente de profesionales. In: ANJINOVICH, Rebeca; CAPPELLETTI, Graciela (org). Las prácticas como eje de la formación docente. Buenos Aires: Eudeba, 2014. p. 12-29.

BECKER, F. Epistemologia do professor. São Paulo: Cortez, 1995.

BRASIL. Relatório de gestão 2009 - 2013. Diretoria de Formação de Professores da Educação Básica - DEB. Brasília: MEC, 2013a.

BRASIL. Ministério da Educação. Capes. Portaria 096 de 18 de julho de 2013. 2013b. Disponível em:

https://www.capes.gov.br/images/stories/download/legislacao/Portaria_096_18jul13_AprovaReg ulamentoPIBID.pdf. Acesso em: 1 abr. 2013.

BRONFMAN, S. V. Comunidades de Prática, Revista Educar, Barcelona, v. 47, n. 1, p. 51-68. 2011. 
DUBOW, M.; SILVA JÚNIOR, J. R.; FERREIRA, M. Atuação da Química em um projeto interdisciplinar no âmbito do PIBID Ciências e Matemática. In: ENCONTRO DE DEBATES SOBRE ENSINO DE QUÍMICA, 34, 2014, Santa Cruz do Sul-RS. Anais... Santa Cruz do Sul: Universidade de Santa Cruz do Sul, 2014. p.777-783. Online.

FAZENDA, I. (org.) O que é interdisciplinaridade? São Paulo: Cortez, 2008.

GATTI, B. A.; BARRETTO, E. S. de S; ANDRÉ M. E. D. A. Políticas docentes no Brasil: um estado da arte. Brasília: UNESCO, 2011.

GODINHO, A. A. M. et al. Ações do Pibid/IFRS para trabalhar com sexualidade, sexo, gravidez e drogas na educação especial. In: ENCONTRO DE DEBATES SOBRE ENSINO DE QUÍMICA, 33., 2013, Ijuí. Anais... Ijuí: UNIJUÍ, 2013. p. 1-7. Online.

IMBERNÓN, F. Formação permanente do professorado: novas tendências. São Paulo: Cortez editora, 2009.

LÜDKE, M.; ANDRÉ, M. E. D. A. Pesquisa em educação: abordagens qualitativas. São Paulo: E.P.U., 2012.

MALDANER, O. A. A formação inicial e continuada de professores de Química. 4. ed. Ijuí: Ed. Unijuí, 2013.

MORAES, R.; GALIAZZI, M. do C. Análise textual discursiva. 2. ed. Ijuí: Editora Unijuí, 2011.

PIMENTA, S. G. Formação de professores: saberes da docência e identidade do professor. v. 3. Presidente Prudente: Nuances, 1997.

PIMENTA, S. G.; LIMA, M. S. L. Estágio e docência: diferentes concepções. Poiésis, Tubarão, v.3, n 4, p. 5-24, jan-mai, 2006.

RAMOS, Maurivan Güntzel; MORAES, Roque. A importância da fala na aprendizagem: Os diálogos na reconstrução do conhecimento em aulas de Ciências. In: VII Encontro Nacional de Pesquisa em Educação em Ciências. Anais... Florianópolis. 2009. pp. 1-12.

RAMOS, M.G.; RIBEIRO, M. E. M; GALIAZZI, M.C. Análise Textual Discursiva em processo: investigando a percepção de professores e licenciandos de Química sobre aprendizagem. Campo Abierto. v. 34, n. 2, 2015.

RIBEIRO, M. E. M. O papel de uma comunidade de prática de professores na promoção do interesse dos alunos em aulas de Química. 2013. Dissertação (Mestrado em Educação em Ciências e Matemática) - Faculdade de Física, Pontifícia Universidade Católica do Rio Grande do Sul, Porto Alegre, 2013.

RIBEIRO, M. E. M. A formação de professores em comunidades de prática por meio da participação no Pibid de Química em instituições de ensino superior no estado do Rio Grande do Sul. 2017. Tese (Doutorado em Educação em Ciências e Matemática) - Faculdade de Física, Pontifícia Universidade Católica do Rio Grande do Sul, Porto Alegre, 2017.

RIBEIRO, M. E. M.; RAMOS, M. G. A estruturação de subprojetos de Química do Pibid na forma de uma Comunidade de Prática: vivências desse modo de formação de professores no Rio Grande do Sul. Revista Thema, Pelotas-RS, v. 16. n 3, p. 636-652, 2019.

RIBEIRO, M. E. M.; RAMOS, M. G. Percepções de professores de ciências e matemática sobre a relação entre perguntar e aprender: um exercício de análise textual discursiva. In: LIMA, V. M. 
do R.; RAMOS, M. G.; PAULA, M. C. (org.). Métodos de análise em pesquisa qualitativa: releituras atuais. Porto Alegre: EDIPUCRS, 2019a.

SANTOS JUNIOR, J. B.; MARCONDES, M. E. R. Grupos colaborativos como ferramenta na reestruturação do modelo didático do professor de Química. Ciência \& Educação, Bauru, v.19, n.3, p.695-713. 2013.

SANTOS, V. C.; ARROIO, A. A formação de professores em comunidades de prática: aspectos teóricos e estudos recentes. Revista Debates em Ensino de Química, Recife, v.1, n. 1, p. 29-35, out. 2015.

SCHÖN, D. Formar Professores como Profissionais Reflexivos. In: NÓVOA, A. Os Professores e sua formação. Lisboa: Dom Quixote, 1992. p. 79-91.

SHULMAN, L. Knowledge and teaching foundations of the new Reform. Harvard Educational Review, Cambridge, v. 57, n. 1, p. 1-22. 1987.

TALANQUER, V. Formación docente: ¿Qué conocimiento distingue a los buenos maestros de química? Educación Química, Cidade do México, v.15, n. 1, p. 60-66. 2004.

TARDIF, M. Saberes docentes e formação profissional. 1 ed. Petrópolis: Vozes, 2014.

UNESCO. A TEACHER FOR EVERY CHILD: Projecting Global Teacher Needs from 2015 to 2030, 2013. Disponível em: http://www.uis.unesco.org/Education/Documents/fs27-2013teachers-projections.pdf. Acesso em: 16 abr. 2017.

WENGER, E. Communities of practice: learning, meaning and identity.1 ed. Cambridge: Cambridge University Press, 1998.

WENGER, E. Communities of practice: learning as a social system, Community Intelligence Labs. 2001. Disponível em: www.co-i-l.com/coil/knowledge-garden/cop/lss.shtml, Acesso em: 26 ago. 2011.

WENGER, E. Communities of practice and social learning systems: the career of a concept. 2009. Disponível em: http://wenger-trayner.com/wp-content/uploads/2012/01/09-10-27-CoPsand-systems-v2.01.pdf. Acesso em: 17 ago. 2016.

Recebido em: 04 de outubro de 2020.

Aceito em: 11 de novembro de 2020. 